\title{
Population and Food Production: Prospects and Challenges for Asia
}

\author{
Gajendra Singh \\ Professor, Agricultural Engineering, and Dean, AIT Extension \\ Asian Institute of Technology \\ P.O. Box 4, Klong Luang, \\ Pathumthani 12120, Thailand \\ Fax: +66 2524 6332; Phone: +66 25246631 \\ E-mail: singhg@ait.ac.th
}

\begin{abstract}
The world population stood at 6,056 million in 2000, with 4,742 million in the less developed regions and 1,314 million in developed regions. Asia accounted for 3,672 million, i.e. about 61 percent of the world total. Currently, 2 out of 5 people in the world live in either China or India. The Green Revolution dramatically improved cereal productivity in Asia and other developing regions, easing the fear of endemic famine. During 1967-2000, per capita worldwide cereal production rose substantially mainly due to increasing cereal yields. While per capita cereal production in the developed world rose from 565 kilograms in 1967 to 665 kilograms in 2000, per capita cereal production in the developing countries rose from 176 kilograms to 253 kilograms during the same period. During the same period, many developing countries experienced rising incomes and shifting consumption patterns, which led to increases in consumption of livestock products, particularly in Asia. The number of foodinsecure people in developing countries declined from 994 million in 1970 to 800 million in 2000. Increases in average per capita food availability are expected in all major regions of the world. However, since available food is not equally distributed to all regions, countries and individuals, a large proportion of developing country population is likely to have access to less food than needed. It has become widely accepted that "political will" is the key ingredient in any recipe for sustainable food security. This paper presents an overview of the food demand and supply situation along with changing trends in population growth. It also discusses possible strategies and guidelines in relation to achieving sustainable food security, particularly in the context of developing countries of Asia.
\end{abstract}

Keywords: Asia, population, food production, food security, sustainability, political will

\section{INTRODUCTION}

It was 29 years ago when world leaders accepted, for the first time at the 1974 World Food Conference in Rome, the common responsibility of the international community to abolish hunger and malnutrition within a decade. At the World Food Summit (WFS) in Rome in 1996, heads of state representing 186 countries affirmed their "common and national commitment to achieving food security for all" and agreed to work toward the achievement of the intermediate goal of "reducing the number of undernourished people to half the present number no later than 2015" (Meyers, 2001). Recognizing the multifaceted nature of food insecurity, the WFS 1996 Plan of Action also contained a number of commitments, each in a

G. Singh. "Population and Food Production: Prospects and Challenges for Asia". Agricultural Engineering International: the CIGR Journal of Scientific Research and Development". Vol. V. Invited Overview Paper. Presented at the Forum on Bioproduction in East Asia:

Technology Development \& Opportunities. ASAE Annual meeting, Las Vegas. 27July2003. 
broad action area relevant for reducing the number of undernourished people and eventually achieving food security for all.

As we enter the $21^{\text {st }}$ century, humanity faces a conspicuous contradiction: the persistence of food insecurity and degradation of natural resources amidst plenty. One of the most morally disgusting features of our shrinking world is that half of the world is preoccupied with dieting and the other half with the struggle to get enough to eat. International meetings have repeatedly issued official declarations that have decried this situation as unacceptable, and agreed on action that would achieve measurable goals related to food security, poverty reduction, and sustainable management of natural resources (Aziz, 2001). Yet, available evidence indicates that few of these goals have been achieved and that, with business as usual, hundreds of millions of people will remain food insecure, millions of children will die each year from malnutrition, and environmental degradation will continue unchecked.

However, there is nothing inevitable about this devastating prospect. If governments, international agencies, civil society, the private sector, and individuals are willing to back their words with action, resources, and changes in behavior and institutions, accelerated progress towards the sustainable food security for all in coming decades is indeed possible without harming the environment.

\section{WORLD POPULATION}

Around the world, populations are experiencing unprecedented change. The most obvious and best-known example is the expansion in human numbers. The world population reached the 6 billion in 1999 (Bongaarts, 2001). It grew at 1.33 per cent per year between 1995 and 2000, which is significantly less than the peak growth rate of 2.04 percent in 19651970, and less than the rate of 1.46 percent in 1990-1995. The annual population increment also declined from its peak of 86 million in 1985-1990 to 78 million in 1995-2000. It will further decline gradually to 64 million in 2015-2020, and then sharply to 30 million in 20452050 growing at the rate of only 0.34 per cent. The world population is expected to reach 7.5 billion in 2020 and 9.3 billion in 2050 (FAO, 2003).

From 1804, when the world passed the 1 billion mark, it took 123 years to reach 2 billion people in 1927, 33 years to attain 3 billion in 1960, 14 years to reach 4 billion in 1974, 13 years to attain 5 billion in 1987 and 12 years to reach 6 billion in 1999. It will take 14 years to reach 7 billion in 2013, 15 years to reach 8 billion in 2028, and, with the slowing down of population growth, it will take 22 years to reach 9 billion, in 2050 (Singh, 2000).

The world population stood at 6,056 million in 2000, with 4,742 million in the less developed regions and 1,314 million in the more developed regions. Asia accounted for 3,672 million, i.e. about 61 per cent of the world total. During this year, Africa's population (794 million) became larger than that of Europe (727 million). The population of Latin America and the Caribbean stood at 519 million and that of Northern America at 314 million in the same year (FAO, 2003).

In 1950, Europe and Northern America accounted for 28.5 percent of the world

G. Singh. "Population and Food Production: Prospects and Challenges for Asia". Agricultural Engineering International: the CIGR Journal of Scientific Research and Development". Vol. V. Invited Overview Paper. Presented at the Forum on Bioproduction in East Asia:

Technology Development \& Opportunities. ASAE Annual meeting, Las Vegas. 27July2003. 
population, their share of the world total decreased to 17.1 in 2000 , and it will further decline to 11.2 percent in 2050 (Table 1). The world population share of Africa increased from 8.8 per cent in 1950 to 13.1 percent in 2000 and is projected to reach 21.5 percent in 2050 . The shares of Asia and Latin America are relatively more stable at approximately 60 and 9 percent, respectively (FAO, 2003).

Table 1. Population of the major regions of the world in 1950, 2000 and 2050

\begin{tabular}{lcccccc}
\hline Region & \multicolumn{3}{c}{ Population in different years } \\
\hline & \multicolumn{2}{c}{$\mathbf{1 9 5 0}$} & \multicolumn{2}{c}{$\mathbf{2 0 0 0}$} & \multicolumn{2}{c}{$\mathbf{2 0 5 0}$} \\
\cline { 2 - 6 } World & Million & Percent & Million & Percent & Million & Percent \\
\cline { 2 - 7 } More developed regions & 2,521 & 100 & 6,056 & 100 & 9,322 & 100 \\
Less developed regions & 813 & 32.2 & 1,314 & 21.7 & 1,335 & 14.3 \\
Africa & 1,709 & 67.8 & 4,742 & 78.3 & 7,987 & 85.7 \\
Asia & 221 & 8.8 & 794 & 13.1 & 2,000 & 21.4 \\
Europe & 1,402 & 55.6 & 3,672 & 60.6 & 5,428 & 58.2 \\
Latin America \& the Caribbean & 547 & 21.7 & 727 & 12.0 & 603 & 6.5 \\
North America & 167 & 6.6 & 519 & 8.6 & 806 & 8.6 \\
\hline Source: FAO (2003) & 172 & 6.8 & 314 & 5.2 & 438 & 4.7 \\
\hline
\end{tabular}

Currently, two out of five people in the world live in either China or India. Sixty percent of the world population increase is contributed by only 10 countries, with 21 per cent contributed by India and 15 percent by China. According to the medium variant, by 20452050, 56 countries will experience a negative population growth, including all European countries, Japan and China. Net population increase during 1995-2000, Human Development Index (HDI), life expectancy, education index, and per capita GDP of ten most populous countries are presented in Table 2.

Table 2. Top ten contributors to world population growth (1995-2000)

\begin{tabular}{|c|c|c|c|c|c|c|}
\hline \multirow[t]{2}{*}{ Country } & \multicolumn{2}{|c|}{ Population } & \multirow{2}{*}{$\begin{array}{c}\text { HDI } \\
\text { value }\end{array}$} & \multirow{2}{*}{$\begin{array}{c}\text { Life } \\
\text { expectancy } \\
\text { (years) }\end{array}$} & \multirow{2}{*}{$\begin{array}{c}\text { Education } \\
\text { index }\end{array}$} & \multirow{2}{*}{$\begin{array}{c}\text { Per capita } \\
\text { GDP(PPP) } \\
(\mathrm{US} \$)\end{array}$} \\
\hline & $\begin{array}{c}\text { Net addition } \\
\text { (millions) }\end{array}$ & Percent & & & & \\
\hline India & 16.0 & 20.6 & .577 & 63.3 & .57 & 2,358 \\
\hline China & 11.4 & 14.7 & .726 & 70.5 & .80 & 3,976 \\
\hline Pakistan & 4.0 & 5.2 & .499 & 60.0 & .42 & 1,928 \\
\hline Indonesia & 2.9 & 3.8 & .684 & 66.2 & .79 & 3,043 \\
\hline Nigeria & 2.5 & 3.2 & .462 & 51.7 & .58 & 896 \\
\hline USA & 2.3 & 2.9 & .939 & 77.0 & .98 & 34,142 \\
\hline Brazil & 2.2 & 2.8 & .757 & 67.7 & .83 & 7,625 \\
\hline Bangladesh & 2.1 & 2.7 & .478 & 59.9 & .40 & 1,602 \\
\hline Mexico & 1.5 & 2.0 & .796 & 72.6 & .84 & 9,023 \\
\hline Philippines & 1.5 & 2.0 & .754 & 69.3 & .91 & 3,971 \\
\hline Sub-total & 46.5 & 59.8 & & & & \\
\hline World total & 77.7 & 100 & & & & \\
\hline
\end{tabular}

Source: UNDP (2003) and UNFPA (2003)

Deevey (1960), as cited by Oerke et al (1994), subdivides the history of mankind into three cultural epochs. The first, which lasted a million years, was the epochs of hunters, gatherers and the first toolmakers. The second, the epoch of agriculture, started about 10,000

G. Singh. "Population and Food Production: Prospects and Challenges for Asia". Agricultural Engineering International: the CIGR Journal of Scientific Research and Development". Vol. V. Invited Overview Paper. Presented at the Forum on Bioproduction in East Asia:

Technology Development \& Opportunities. ASAE Annual meeting, Las Vegas. 27July2003. 
years ago; this was a settled way of life and marked the beginnings of modern civilization in the various parts of the world. The last epoch was the rise of science and the industrialization. Hunters and gatherers used their own energy. Farming, involving the use of draught and pack animals and irrigation systems, increased the available energy many times over. With the rise of science and industrialization came the means of energy production from fossil fuels (coal, oil and gas) and non-fossil fuels (nuclear and solar energy, wind power), which have provided a much more broad based supply of energy for growth in food production.

\section{WORLD FOOD SITUATION}

\subsection{Trends in Food Demand and Supply}

World food situation underwent dramatic changes during three decades since the mid1960s, when widespread food shortages in Asia caused predictions of disastrous recurring famines. The Green Revolution, featuring the adoption of high-yielding cereal varieties and rapid increases in irrigated area and fertilizer use, dramatically improved productivity in Asia and other developing regions, easing the fear of endemic famine. The Green Revolution peaked in much of Asia in the 1970s and early 1980s. Concurrently with the Green Revolution, many developing countries experienced rising incomes and shifting consumption patterns, which led to striking increases in consumption of livestock products, particularly in Asia.

Food demand growth caused by expanding populations and shifting consumption patterns will necessitate future food production increases, but unexploited, available arable land is limited, placing the burden for these increases on technology driven yield improvements. Empirical evidence has demonstrated that negative effects on the environment from inappropriately applied technologies can translate into productivity losses and threaten human health. Growing urban and industrial demands on existing water supplies and the need for improved water quality further complicate the situation.

\subsection{Cereal Production}

During 1967-2000, per capita worldwide cereal production rose substantially in the context of rapidly increasing cereal yields, slow growth in total harvested area, and declining per capita harvested area. While per capita cereal production in the developed world rose from 565 kilograms in 1967 to 665 kilograms in 2000, per capita cereal production in the developing world rose from 176 kilograms in 1967 to 253 kilograms during the same period (Table 3).

G. Singh. "Population and Food Production: Prospects and Challenges for Asia". Agricultural Engineering International: the CIGR Journal of Scientific Research and Development". Vol. V. Invited Overview Paper. Presented at the Forum on Bioproduction in East Asia:

Technology Development \& Opportunities. ASAE Annual meeting, Las Vegas. 27July2003. 
Table 3. Per capita cereal production and annual growth rates in different regions of the world

\begin{tabular}{lccccccc}
\hline Region & \multicolumn{3}{c}{$\begin{array}{c}\text { Per capita cereal production } \\
\text { (in kg) }\end{array}$} & \multicolumn{3}{c}{$\begin{array}{c}\text { Production growth rates } \\
\text { (percent per year) }\end{array}$} \\
\cline { 2 - 8 } & 1967 & 1982 & 1997 & 2000 & $1967-$ & $1982-$ & $1997-$ \\
& & & & & 1982 & 1997 & 2000 \\
\hline Latin America & 225.3 & 262.0 & 253.4 & 265.5 & 1.0 & -0.6 & 2.2 \\
Sub-Saharan Africa & 127.9 & 110.8 & 124.6 & 120.9 & -1.0 & 0.3 & -0.1 \\
All Asia & 163.6 & 206.9 & 236.4 & 272.2 & 1.6 & 0.7 & 1.4 \\
South Asia & 146.0 & 171.3 & 182.6 & 239.7 & 1.1 & 0.8 & 1.8 \\
South-East Asia & 157.8 & 198.8 & 226.3 & 238.2 & 1.6 & 1.1 & 1.6 \\
East Asia & 188.7 & 248.7 & 295.8 & 310.9 & 1.9 & 1.0 & 0.7 \\
Developed world & 564.6 & 670.4 & 660.1 & 665.4 & 1.2 & -0.4 & 0.0 \\
Developing world & 176.0 & 206.8 & 225.6 & 253.3 & 1.1 & 0.6 & 1.1 \\
\hline Source: FAO (2003) and Rosegrant et al (2001) & \multicolumn{3}{c}{}
\end{tabular}

\subsection{Cereal Demand}

Income and population growth have driven expansion of cereal demand worldwide. The gradual slowing in population growth rates over recent decades has resulted in a corresponding slowdown in the rate of growth in cereal demand (Table 4). Cereal demand growth in the developing world declined from 3.8 percent annually in 1967-82 to 2.7 percent in 1982-97, and to 2.2 percent in 1997-2000. However, such aggregate growth rates obscure as much as they reveal; decline in Asia have driven the overall demand growth downward, since that region accounts for about 60 percent of the world population and dominates trends at the global level. Poverty and a scarcity of foreign exchange restrained demand growth in Sub-Saharan Africa, despite persistent high malnutrition in the region.

Table 4. Growth rates of population and total cereal demand in different regions of the world

\begin{tabular}{lcccccc}
\hline Region & \multicolumn{3}{c}{$\begin{array}{c}\text { Population growth rate } \\
\text { (percent per year) }\end{array}$} & $\begin{array}{c}\text { Total cereal demand growth rate } \\
\text { (percent per year) }\end{array}$ \\
\hline & $1967-$ & $1982-$ & $1997-$ & $1967-1982$ & $1982-1997$ & $1997-2000$ \\
& 1982 & 1997 & 2000 & & & \\
\hline Latin America & 2.4 & 1.7 & 1.5 & 4.0 & 3.6 & 3.8 \\
Sub-Saharan Africa & 2.8 & 2.6 & 2.2 & 2.8 & 4.0 & 4.3 \\
All Asia & 2.2 & 1.6 & 1.4 & 3.8 & 2.6 & 2.1 \\
South Asia & 2.3 & 1.9 & 1.6 & 2.9 & 2.6 & 2.2 \\
South-East Asia & 2.4 & 1.7 & 1.3 & 2.8 & 3.4 & 3.1 \\
East Asia & 2.0 & 1.1 & 0.8 & 4.3 & 2.4 & 1.9 \\
Developing world & 2.3 & 1.7 & 1.6 & 3.8 & 2.7 & 2.2 \\
Developed world & 0.8 & 0.5 & 0.3 & 1.9 & -1.3 & -1.8 \\
\hline
\end{tabular}

Source: FAO (2003); UNFPA (2003); and Rosegrant et al (2001)

\subsection{Cereal Trade}

Growth in production and demand in a number of regions has resulted in a dramatic increase in world cereal trade from about 116 million metric tons in 1967 to 272 million

G. Singh. "Population and Food Production: Prospects and Challenges for Asia". Agricultural Engineering International: the CIGR Journal of Scientific Research and Development". Vol. V. Invited Overview Paper. Presented at the Forum on Bioproduction in East Asia:

Technology Development \& Opportunities. ASAE Annual meeting, Las Vegas. 27July2003. 
metric tons in 2000. Most of this increase in cereal trade took place between 1967 and 1982, when total cereal trade expanded at a rate of 5.1 percent annually. Growth slowed between 1982 and 1990 to 0.5 percent annually but picked up to a rate of 1.1 percent between 1990 and 2000 (Rosegrant et al, 2001). The growth in cereal trade has been influenced by rapid economic growth in developing countries, as well as much improved communication and transportation facilities, and changing patterns of food demand (Dyson, 1996). Table 5 gives a breakdown of net cereal trade by regions.

Table 5. Net cereal trade (in million metric tons) by region

\begin{tabular}{lcccc}
\hline Region & $\mathbf{1 9 6 7}$ & $\mathbf{1 9 8 2}$ & $\mathbf{1 9 9 0}$ & $\mathbf{2 0 0 0}$ \\
\hline Latin America & 3.1 & -3.5 & -11.4 & -16.8 \\
Sub-Saharan Africa & -1.5 & -8.3 & -8.1 & -14.2 \\
All Asia & -17.4 & -28.0 & -29.4 & -26.5 \\
South Asia & -11.6 & -2.9 & -3.2 & -0.9 \\
South-East Asia & -0.1 & 0.8 & 0.1 & -6.5 \\
East Asia & -5.8 & -25.9 & -26.3 & -19.1 \\
Developing world & -21.7 & -68.7 & -87.6 & -99.8 \\
Developed world & 24.6 & 73.8 & 93.2 & 110.4 \\
\hline
\end{tabular}

Source: FAO (2003) and Rosegrant et al (2001)

Note: (+) figures indicate export; (-) figures indicate imports

\subsection{Food Availability}

According to IFPRI, during the next quarter century the world will produce enough food to meet the demand of people who can afford to buy it (Table 6), and real food prices will continue to decline (Table 7).

Table 6. Projected average annual growth rates in production of major commodities

\begin{tabular}{|c|c|c|c|c|c|c|c|c|c|}
\hline \multirow{2}{*}{ Commodity } & \multicolumn{3}{|c|}{ World } & \multicolumn{3}{|c|}{ Developed countries } & \multicolumn{3}{|c|}{ Developing countries } \\
\hline & Area & Yield & Production & Area & Yield & Production & Area & Yield & Production \\
\hline$\overline{\text { Beef }}$ & - & - & 1.43 & - & - & 0.90 & - & - & 2.26 \\
\hline Pig meat & - & - & 2.04 & - & - & 0.61 & - & - & 3.28 \\
\hline Sheep meat & - & - & 2.30 & - & - & 1.34 & - & - & 2.90 \\
\hline Poultry & - & - & 1.99 & - & - & 1.23 & - & - & 3.03 \\
\hline Total meat & - & - & 1.87 & - & - & 0.89 & - & - & 2.95 \\
\hline Eggs & - & - & 2.20 & - & - & 0.86 & - & - & 3.23 \\
\hline Wheat & 0.19 & 1.35 & 1.55 & 0.01 & 0.99 & 1.00 & 0.39 & 1.77 & 2.17 \\
\hline Rice & 0.19 & 1.43 & 1.62 & 0.10 & 0.76 & 0.86 & 0.19 & 1.46 & 1.66 \\
\hline Maize & 0.40 & 1.08 & 1.49 & 0.07 & 0.92 & 0.99 & 0.56 & 1.52 & 2.09 \\
\hline Other coarse grains & 0.28 & 1.02 & 1.31 & 0.00 & 0.94 & 0.94 & 0.57 & 1.48 & 2.05 \\
\hline Total cereals & 0.26 & 1.24 & 1.50 & 0.02 & 0.96 & 0.97 & 0.40 & 1.54 & 1.94 \\
\hline Roots and tubers & 0.47 & 0.90 & 1.38 & 0.02 & 0.74 & 0.76 & 0.61 & 1.04 & 1.65 \\
\hline Soybean & 0.45 & 1.47 & 1.92 & 0.38 & 1.40 & 1.78 & 0.50 & 1.56 & 2.08 \\
\hline
\end{tabular}

Source: IFPRI (2001) and Rosegrant et al (2001)

G. Singh. "Population and Food Production: Prospects and Challenges for Asia". Agricultural Engineering International: the CIGR Journal of Scientific Research and Development". Vol. V. Invited Overview Paper. Presented at the Forum on Bioproduction in East Asia:

Technology Development \& Opportunities. ASAE Annual meeting, Las Vegas. 27July2003. 
Table 7. Projected real world prices of major commodities, 1990 and 2020

\begin{tabular}{lccc}
\hline Commodity & $\mathbf{1 9 9 0}$ & $\mathbf{2 0 2 0}$ & Change \\
\hline Wheat & (In 1990 US\$ per metric ton) & (Percent) \\
Rice & 156 & 132 & -15 \\
Maize & 231 & 181 & -22 \\
Other course grains & 109 & 84 & -23 \\
Soybean & 89 & 67 & -25 \\
Roots and tubers & 247 & 219 & -11 \\
Beef & 148 & 122 & -18 \\
Pigmeat & 2,062 & 1,947 & -6 \\
Sheepmeat & 1,664 & 1,500 & -10 \\
Poultry & 1,907 & 1,825 & -4 \\
Eggs & 739 & 662 & -10 \\
\hline Total cereals & 897 & 668 & -26 \\
\hline Total meats & $\mathbf{1 4 4}$ & $\mathbf{1 1 6}$ & $\mathbf{- 1 9}$ \\
\hline Source Rosegrant & $\mathbf{1 , 5 8 7}$ & $\mathbf{1 , 4 4 1}$ & $\mathbf{- 9}$ \\
\hline
\end{tabular}

Source: Rosegrant et al (1995)

Worldwide, per capita availability of food calories is given in Table 8 and that of protein is given in Table 9. The former is projected to increase around 7 percent between 1993 and 2020, from about 2,700 calories per person per day in 1993 to about 2,900 calories in 2020 (Table10). Increases in average per capita food availability are expected in all major regions. China and East Asia are projected to experience the largest increase, and West Asia and North Africa the smallest. The projected average availability of about 2,300 calories per person per day in Sub-Saharan Africa is just barely above the minimum required for a healthy and productive life. Since available food is not equally distributed to all regions, countries, and individuals, a large proportion of developing world population is likely to have access to less food than needed.

Table 8. Per capita food availability during 1961-2000 (calories/day)

\begin{tabular}{lccccc}
\hline Year & World & $\begin{array}{c}\text { Developed } \\
\text { countries }\end{array}$ & $\begin{array}{c}\text { Developing } \\
\text { countries }\end{array}$ & China & India \\
\hline $1961-65$ & 2,308 & 2,995 & 1,994 & 1,789 & 2,047 \\
$1966-70$ & 2,376 & 3,093 & 2,071 & 1,974 & 1,970 \\
$1971-75$ & 2,417 & 3,151 & 2,127 & 2,046 & 1,995 \\
$1976-80$ & 2,495 & 3,206 & 2,230 & 2,193 & 2,043 \\
$1981-85$ & 2,607 & 3,237 & 2,388 & 2,521 & 2,146 \\
$1986-90$ & 2,679 & 3,315 & 2,475 & 2,625 & 2,266 \\
$1991-95$ & 2,698 & 3,223 & 2,545 & 2,697 & 2,357 \\
$1996-2000$ & 2,706 & 3,252 & 2,594 & 3,029 & 2,428 \\
\hline
\end{tabular}

Source: FAO (2003)

G. Singh. "Population and Food Production: Prospects and Challenges for Asia". Agricultural Engineering International: the CIGR Journal of Scientific Research and Development". Vol. V. Invited Overview Paper. Presented at the Forum on Bioproduction in East Asia:

Technology Development \& Opportunities. ASAE Annual meeting, Las Vegas. 27July2003. 
Table 9. Per capita protein availability during 1961-2000 (grams/day)

\begin{tabular}{lccccc}
\hline Year & World & $\begin{array}{c}\text { Developed } \\
\text { countries }\end{array}$ & $\begin{array}{c}\text { Developing } \\
\text { countries }\end{array}$ & China & India \\
\hline $1961-65$ & 63.26 & 90.46 & 50.80 & 46.20 & 52.12 \\
$1966-70$ & 64.08 & 93.44 & 51.68 & 47.92 & 49.82 \\
$1971-75$ & 64.60 & 95.94 & 52.28 & 48.48 & 49.54 \\
$1976-80$ & 65.92 & 97.84 & 54.20 & 51.00 & 50.28 \\
$1981-85$ & 68.42 & 98.80 & 57.94 & 58.60 & 52.88 \\
$1986-90$ & 70.64 & 102.32 & 60.52 & 62.84 & 55.54 \\
$1991-95$ & 71.42 & 98.56 & 63.18 & 67.78 & 56.68 \\
$1996-2000$ & 72.86 & 101.66 & 65.34 & 70.00 & 59.02 \\
\hline
\end{tabular}

Source: FAO (2003)

Table 10. Per capita food availability in 1990 and 2020 (calories/day)

\begin{tabular}{lll}
\hline Country/Region & $\mathbf{1 9 9 0}$ & $\mathbf{2 0 2 0}$ \\
\hline World & 2,773 & 2,888 \\
Developed world & 3,353 & 3,517 \\
Developing world & 2,500 & 2,834 \\
Latin America \& the Caribbean & 2,722 & 3,054 \\
Sub-Saharan Africa & 2,053 & 2,136 \\
Near East \& North America & 2,988 & 3,301 \\
Asia & 2,500 & 2,999 \\
\hline
\end{tabular}

Source: FAO (2003)

\section{FOOD SITUATION IN ASIA}

\subsection{Growth in Cereal Production}

The Green Revolution had a dramatic effect on food security in Asia. It enabled the two most populous countries in the region, China and India, to escape rising import dependence and periodic food shortages. Recent signs indicate that phenomenal Green Revolution growth in rice and wheat productivity is slowing, especially in the intensively cultivated lowlands. Since the early 1990s, rising production costs have led to a decline in farmer profits in both India and China.

Rice, wheat and maize are three major crops in most Asian countries. During 19802000, production of these crops increased steadily in all parts of Asia (Table 11). Total harvested area of rice narrowly increased in South Asia, and East and South-East Asia. However, it declined in China and India. Rice yield increased in all Asian regions during this period, which contributed to increase in total production. Due to population growth it is less likely to expand rice harvested area in most Asian countries. So, further increase in rice production in Asia would result from yield improvement. Asia has potential to improve its rice yield from present $2.6 \mathrm{t} / \mathrm{ha}$ to $6 \mathrm{t} / \mathrm{ha}$ if modern inputs and production technologies are applied under existing agro-climatic condition.

G. Singh. "Population and Food Production: Prospects and Challenges for Asia". Agricultural Engineering International: the CIGR Journal of Scientific Research and Development". Vol. V. Invited Overview Paper. Presented at the Forum on Bioproduction in East Asia:

Technology Development \& Opportunities. ASAE Annual meeting, Las Vegas. 27July2003. 
Table 11. Total harvested area, yield and production of rice, wheat and maize in Asia

\begin{tabular}{|c|c|c|c|c|c|c|c|c|c|}
\hline \multirow[t]{2}{*}{ Region } & \multicolumn{3}{|c|}{1980} & \multicolumn{3}{|c|}{1990} & \multicolumn{3}{|c|}{2000} \\
\hline & $\begin{array}{c}\text { Area } \\
\text { (million } \\
\text { ha) }\end{array}$ & $\begin{array}{c}\text { Yield } \\
\text { (tons/ha) }\end{array}$ & $\begin{array}{c}\text { Production } \\
\text { (million } \\
\text { tons) }\end{array}$ & $\begin{array}{c}\text { Area } \\
\text { (million } \\
\text { ha) }\end{array}$ & $\begin{array}{c}\text { Yield } \\
\text { (tons/ha) }\end{array}$ & $\begin{array}{l}\text { Production } \\
\text { (million } \\
\text { tons) }\end{array}$ & $\begin{array}{c}\text { Area } \\
\text { (million } \\
\text { ha) }\end{array}$ & $\begin{array}{c}\text { Yield } \\
\text { (tons/ha) }\end{array}$ & $\begin{array}{l}\text { Production } \\
\text { (million } \\
\text { tons) }\end{array}$ \\
\hline \multicolumn{10}{|c|}{ Rice } \\
\hline China & 95.1 & 2.4 & 232.7 & 93.6 & 3.6 & 340.6 & 85.0 & 4.0 & 344.1 \\
\hline India & 104.0 & 1.1 & 113.6 & 102.5 & 1.5 & 156.8 & 102.4 & 1.9 & 195.3 \\
\hline South & 128.7 & 1.2 & 148.6 & 129.6 & 1.6 & 201.4 & 131.1 & 2.0 & 258.1 \\
\hline Asia & & & & & & & & & \\
\hline East \& & 47.4 & 1.6 & 77.7 & 50.1 & 2.0 & 103.6 & 54.3 & 2.4 & 131.0 \\
\hline South- & & & & & & & & & \\
\hline East Asia & & & & & & & & & \\
\hline All Asia & 304.8 & 1.7 & 512.1 & 310.6 & 2.3 & 713.6 & 302.9 & 2.6 & 796.0 \\
\hline \multicolumn{10}{|c|}{ Wheat } \\
\hline China & 29.2 & 1.9 & 55.2 & 30.8 & 3.2 & 98.2 & 26.6 & 3.7 & 99.6 \\
\hline India & 22.2 & 1.4 & 31.8 & 23.5 & 2.1 & 49.8 & 27.5 & 2.8 & 76.4 \\
\hline South & 29.9 & 1.5 & 44.0 & 32.5 & 2.0 & 65.9 & 37.5 & 2.7 & 100.5 \\
\hline Asia & & & & & & & & & \\
\hline East \& & 0.6 & 0.8 & 0.5 & 0.8 & 1.1 & 0.8 & 0.3 & 0.9 & 0.3 \\
\hline South- & & & & & & & & & \\
\hline East Asia & & & & & & & & & \\
\hline All Asia & 80.0 & 1.6 & 129.1 & 85.2 & 2.4 & 203.1 & 84.7 & 2.8 & 237.4 \\
\hline \multicolumn{10}{|c|}{ Maize } \\
\hline China & 20.4 & 3.1 & 62.7 & 21.5 & 4.5 & 97.2 & 23.1 & 4.6 & 106.2 \\
\hline India & 6.0 & 1.2 & 7.0 & 5.9 & 1.5 & 9.0 & 6.6 & 1.8 & 12.0 \\
\hline South & 7.3 & 1.2 & 8.8 & 7.6 & 1.5 & 11.5 & 8.5 & 1.8 & 15.2 \\
\hline Asia & & & & & & & & & \\
\hline East \& & 8.7 & 1.6 & 13.7 & 9.9 & 2.0 & 20.6 & 8.8 & 2.5 & 22.5 \\
\hline South- & & & & & & & & & \\
\hline East Asia & & & & & & & & & \\
\hline All Asia & 37.6 & 2.3 & 87.4 & 40.0 & 3.3 & 132.5 & 41.4 & 3.6 & 147.9 \\
\hline
\end{tabular}

During 1980-2000, total harvested area of wheat increased slightly in South Asia. However, it declined in China, and East and South-East Asia. During this period, yield of wheat almost doubled in China, India and other parts of South Asia, which contributed to significant increase in total production. In East and South-East Asia, during the same period, total harvested area of wheat declined by 50 percent, and yield remained stagnant, which sharply decreased total production of this crop. It is expected that due to land suitability and continuing market demand, China and South Asian countries will be able to increase their total wheat production through yield improvement.

In Asia, maize is mainly used for livestock and poultry feed. During 1990-2000, total harvested area of maize increased slightly in this region. Total production of this crop increased steadily during this period mainly due to yield increase. In most Asian countries, because of rapid urbanization and per capita income growth, the demand of livestock and poultry products has been increasing sharply in recent years. Newly established livestock and poultry industries are creating increased demand for maize and other coarse grains. Because of land scarcity, further increase in total maize production in Asian countries is expected to result from yield improvement.

G. Singh. "Population and Food Production: Prospects and Challenges for Asia". Agricultural Engineering International: the CIGR Journal of Scientific Research and Development". Vol. V. Invited Overview Paper. Presented at the Forum on Bioproduction in East Asia:

Technology Development \& Opportunities. ASAE Annual meeting, Las Vegas. 27July2003. 


\subsection{Population and Food Situation in Different Regions of Asia}

\subsubsection{South Asia}

Cereals play dominant role in South Asian food scenario because of their paramount importance in the sub-region's diet. IFPRI baseline projections indicate that wheat imports in South Asia will grow at 6.4 percent per year between 2000 and 2020. This increase is due to continued strong demand growth (in part because of high population growth in Pakistan) together with a slowdown in production, especially in Pakistan, where the bulk of wheat demand will come from. Rice will be almost in balance, in contrast to the large export in the base year. This will result due to reduced rates of production growth, particularly in Bangladesh and Pakistan. Imports of maize and other coarse grains will also expand, and most will be used as feeds to support the expansion of livestock industry (Rosegrant et al, 2001).

With a population of one billion mark in year 2000, India is the second most populous country in the world after China. Like China more than a decade ago, India is in the midst of major economic reform. If it succeeds, incomes in India will rise much faster than they have in recent decades, with profound effects on food demand and food security. India is projected to have an average annual economic growth rate of 5.5 percent during 1993-2020. Daily per capita calorie availability is projected to increase from around 2,266 calories in 1990 to 2,780 calories in 2020 (Singh, 2000).

India with a total land area of 328 million hectare represents all kinds of climate and is demarcated into 20 agroclimatic zones. An estimated 142 million hectare is cultivated area, of which about 55 million hectare is irrigated and remainder 87 million hectares is rainfed. The increase in the production of foodgrain and other agricultural commodities has kept pace with the increase in the population since 1961 (Table 12).

Table 12. Population and food in India

\begin{tabular}{cccccccc}
\hline Year & $\begin{array}{c}\text { Population } \\
\text { (million) }\end{array}$ & $\begin{array}{c}\text { Foodgrain } \\
\text { (million ton) }\end{array}$ & $\begin{array}{c}\text { Milk } \\
\text { (million ton) }\end{array}$ & $\begin{array}{c}\text { Egg } \\
\text { (billion) }\end{array}$ & $\begin{array}{c}\text { Fish } \\
\text { (million ton) }\end{array}$ & $\begin{array}{c}\text { Potato } \\
\text { (million ton) }\end{array}$ & $\begin{array}{c}\text { Sugarcane } \\
\text { (million ton) }\end{array}$ \\
\hline 1961 & 439.2 & 82.0 & - & - & 1.2 & 2.7 & 110.0 \\
1971 & 548.2 & 108.4 & - & - & 1.8 & 4.8 & 126.4 \\
1981 & 685.2 & 129.6 & 31.6 & 10.6 & 2.4 & 9.7 & 154.3 \\
1991 & 846.3 & 176.4 & 53.9 & 21.1 & 3.8 & 15.2 & 241.1 \\
2000 & $1,008.0$ & 208.9 & 78.1 & 31.5 & 5.7 & 25.0 & 299.0 \\
\hline \multicolumn{5}{l}{ Source: ICAR (2002) }
\end{tabular}

In India, production of rice, wheat and maize is projected to grow faster than 2.0 percent per year, and production of other coarse grains will grow by 1.9 percent (Kerr, 2000). At the projected level of effective demand, India's agricultural trade position will be sound. Although meat imports will increase as demand grows quickly from a low base, they will remain small relative to the size of the Indian economy. India will manage to be a marginal exporter of cereals, while exports of maize and other coarse grains will be small because production will cater primarily to local demand for livestock feed.

G. Singh. "Population and Food Production: Prospects and Challenges for Asia". Agricultural Engineering International: the CIGR Journal of Scientific Research and Development". Vol. V. Invited Overview Paper. Presented at the Forum on Bioproduction in East Asia:

Technology Development \& Opportunities. ASAE Annual meeting, Las Vegas. 27July2003. 
Regarding food demand-supply situation, more serious problems are expected to emerge in Pakistan and other South Asian countries. Wheat imports are projected to grow from 2.1 million tons in 1990 to 15.5 million tons in 2020. The rapidly increasing gap occurs despite relatively strong growth in wheat production ( 2.2 percent), as demand grows at about 3.2 percent per year, owing in large part to rapid population growth of 2.8 percent. Imports will also grow for maize and other coarse grains. Among the cereals, only rice will continue to be exported, but at reduced levels. Pakistan's growing trade gap is accompanied by a worsening of its food security position. There are little projected improvements in per capita food availability through 2020, and the number of malnourished pre-school children will increase by nearly nine percent. Similar (though less severe) problems will arise in the aggregate grouping of other South Asian countries (Rosegrant et al, 2001).

Bangladesh made steady progress in food production in the post-independence period. Rice is the dominant crop and largely determines the rate of progress in agricultural sector of the country. As stated by BBS (2001), in 1994-95 total food grain production of the country was 18.17 million tons compared to the target of 20 million tons, as a result of declining prices and natural disasters (particularly floods and droughts). The situation improved in the subsequent years and the food grain production was about 20.4 million tons in 2000. The total population of Bangladesh is estimated to reach 132.50 million by the end of 2003. In order to feed them the country will need 21.94 million tons of food grains. Food production has been estimated at 25.12 million tons in 2002-03. Thus the country is likely to attain food selfsufficiency by the end of 2003.

The population of Sri Lanka increased from 6.7 million in 1947 to 19.1 million in 2001. The country has a land area of 64,454 sq kilometers of which 60 percent is cultivable. About 35 percent of the cultivated area is under rice while 42 percent is under tea and rubber. The GDP share of agriculture started to decline from 46 percent in 1960 to 23 percent in 1995, and to 20 percent in 1997 (CBSL, 2000). The overall production in agricultural sector of the country has affected by ethnic conflict. According to FAO, the productivity of inputs used in agriculture was lowest in Sri Lanka among all Asian countries during 1984-1993. Government interventions in commodity and factor markets in agriculture are largely relaxed in recent years following heavy state regulation in the initial years since independence. As a whole, since 1997, the agriculture sector has been moving towards improved market efficiency with macro-economic reform. It is expected that during coming years the country will be able to improve its food security situation both by expediting food grain production and increasing foreign currency reserve by exporting tea, coconut and other cash crops.

The population of Nepal increased from 15 million in 1981 to 24 million in 2001 (UNFPA, 2003). The population pressure on land has forced encroachment of arable land into forest. Land has become fragmented under the existing laws of inherited property. A vicious cycle in land use contributes to low productivity and does not permit the development of agriculture on a commercial scale. The overall development objectives of all Five-Year Plans of Nepal are focused on increasing food production to meet the dietary needs of growing population. Rice, wheat, maize, millet and barley are common food crops. The three major food crops - rice, wheat and maize contribute about 51 percent, 25 percent and 16 percent of the total food production, respectively. The hills are food deficit areas. At the aggregate level, there are 38 food deficit districts, which is more than half of the total area of the country

G. Singh. "Population and Food Production: Prospects and Challenges for Asia". Agricultural Engineering International: the CIGR Journal of Scientific Research and Development". Vol. V. Invited Overview Paper. Presented at the Forum on Bioproduction in East Asia:

Technology Development \& Opportunities. ASAE Annual meeting, Las Vegas. 27July2003. 
(Joshi and Poundyal, 1998). Due to relatively higher population growth rate and low productivity in agriculture, the country will continue to import food grains from India and other countries to improve and stabilize food security of its population.

\subsubsection{South-East Asia}

South-East Asia is projected to be one of the dynamic regions over the next three decades. According to Pandey (2000), the rice situation in South-East Asia will be characterized by: i) moderate to strong increases in yields in Indonesia and the Philippines; ii) strong area growth in other South-East Asian countries (particularly Myanmar); iii) very slow growth in demand in Malaysia and Thailand; and iv) modest demand growth elsewhere in the region. The last two effects are due to diversification of diets out of rice as a result of urbanization and continued strong growth in incomes. As a result, the regional export surplus in rice will be more than double over next 30 years, from 4.7 million tons to 11.5 million tons (Rosegrant et al, 2001). With a shift in dietary composition, per capita cereal demand in South-East Asia is projected to increase by only 16 percent, while per capita demand for meat will be doubled by 2020 (FAO, 2003).

Imports of other cereals will increase rapidly owing to strong income growth in the region, which will induce a shift from rice to wheat for direct consumption and cause an increase in demand for maize and other coarse grains for livestock feed. As projected by Rosegrant et al (2001), wheat imports will more than double by 2020, to about 10 million tons, and import of maize and other coarse grains will amount to eight million tons. At present, Thailand is a net exporter of maize; but gradual shift in demand and production patterns will change the present status of this country to an importer of 2.1 million tons of maize by 2020 to meet its rapidly growing pig and poultry sectors.

Starting in the middle of 1997, the economy of Thailand entered a serious recession. The agriculture sector was affected along with other sectors of the economy in recent years. The population of Thailand reached about 64 million with an annual growth rate of 1.34 percent in 2001. More than 42 percent of total land of the country is under agriculture. The annual growth in agricultural production declined from 3.8 percent in 1990 to 1.8 percent in 1997 (Roonnaphai, 1998). Due to relatively low population growth rate and intensification in food grain, livestock, fisheries and horticultural production, Thailand is expected to strengthen its food security situation in coming decades.

Indonesia is the biggest archipelago in the world. The total population of Indonesia increased from 179 million in 1990 to 212 million in 2000 (UNFPA, 2003). Agricultural development in Indonesia has been impressive during 1975 to 2000 with an average annual growth rate of 3.6 percent. Total cereal production of the country increased from 25.2 million tons in 1975 to 61.6 million tons in 2000 (FAO, 2003). This rapid growth in economy changed consumption patterns of people. Consumption of traditional staples has declined and resulted in diversification of agriculture. All long-term development plans of Indonesia emphasized the sub-sectors of livestock, fisheries, food crops, and horticultural crops, and stressed the importance of agro-business and agro-industry development (Suhaeti, 1998). Future economic growth is expected to generate further diversification in food patterns. The per capita consumption of traditional staples will decline and demand for fish and meat will increase in coming years.

G. Singh. "Population and Food Production: Prospects and Challenges for Asia". Agricultural Engineering International: the CIGR Journal of Scientific Research and Development". Vol. V. Invited Overview Paper. Presented at the Forum on Bioproduction in East Asia:

Technology Development \& Opportunities. ASAE Annual meeting, Las Vegas. 27July2003. 
The total population of Vietnam reached 80 million in 2001 with an annual growth rate of 1.4 percent (UNFPA, 2003). The country is suitable for rice cultivation and about 100 varieties of rice are grown in 80-90 percent of total cultivated land (Hai, 1998). The total production of rice increased from 10.6 million tons in 1975 to 34.5 million tons in 2000 (FAO, 2003). After satisfying domestic need the country had an exportable surplus 3.6 million tons of rice in that year. It is expected that Vietnam will be able to meet the food demand of its population in coming decades.

The Philippine population doubled between 1965 and 1995, and is projected to increase by 55 percent in 2025. During 1965-1995, average per capita food availability increased from 1,799 calories to 2,366 calories (FAO, 2003). The agriculture and service sectors are the major sources of economic growth in the Philippines. The annual growth rate in crop, fishery, and forestry rose 3.7 percent in 2001 compared to 3.4 percent in 2000 (NEDA, 2001). According to the report of the Department of Agriculture, crop production, which accounted for 53 percent on total agricultural output, grew by 2.58 percent in 2001 . Increases in yield and area harvested were noticeable during this year. For some agricultural commodities, the encouraging prices and demand pushed the total area harvested upward. With favourable climate and less fluctuation in domestic and international food markets, the country is expected to increase its food production in coming years.

\subsubsection{China}

With one-fifth of the world's population and one of the fastest-growing and most rapidly transforming economies in the world, China has the potential to significantly affect global food security depending on the extent of its future demand for cereals, its capacity to meet its needs through production, and the degree to which it enters world markets to satisfy its unmet needs. Concerns about how China will meet its food requirements escalated recently when China shifted from being a minor net exporter of cereals in 1992-94 to a substantial net importer in 1995. According to Singh (2000), China has since returned to past levels of virtual self-sufficiency in grain, with small net cereal imports of 2-4 million tons annually. In any case, the concerns arising from China's shift to being a net cereal importer in 1995 seem misplaced given that China has been a net importer in 13 of the 18 years since 1980 .

Views on the size and dominance of China's food economy in the $21^{\text {st }}$ century vary widely, with some forecasting that China will be a major cereal exporter and others cautioning that China might become a major cereal importer, if not the world's largest importer. As projected by Rosegrant et al (2001) in the baseline scenario, total cereal demand in China will increase by 42 percent, to 490 million tons, between 1993 and 2020, and cereal production by 31 percent, to 449 million tons. At 41 million tons, China's net cereal imports in 2020 would represent 18 percent of the developing world's projected net cereal imports. For meat, China's production is projected to almost keep up with increases in demand. China is already a significant player in world food markets and is likely to become increasingly more important in coming decades. The trends in population growth and production of main agricultural commodities during 1961-2000 are shown in Table 13.

G. Singh. "Population and Food Production: Prospects and Challenges for Asia". Agricultural Engineering International: the CIGR Journal of Scientific Research and Development". Vol. V. Invited Overview Paper. Presented at the Forum on Bioproduction in East Asia:

Technology Development \& Opportunities. ASAE Annual meeting, Las Vegas. 27July2003. 
Table 13. Population and food in China

\begin{tabular}{cccccccc}
\hline Year & $\begin{array}{c}\text { Population } \\
\text { (million) }\end{array}$ & $\begin{array}{c}\text { Foodgrain } \\
\text { (million ton) }\end{array}$ & $\begin{array}{c}\text { Milk } \\
\text { (million ton) }\end{array}$ & $\begin{array}{c}\text { Egg } \\
\text { (million ton) }\end{array}$ & $\begin{array}{c}\text { Fish } \\
\text { (million ton) }\end{array}$ & $\begin{array}{c}\text { Potato } \\
\text { (million ton) }\end{array}$ & $\begin{array}{c}\text { Sugarcane } \\
\text { (million ton) }\end{array}$ \\
\hline 1961 & 672.7 & 109.7 & 1.8 & 1.5 & 3.2 & 12.9 & 12.4 \\
1971 & 855.7 & 212.1 & 2.0 & 2.0 & 4.3 & 22.0 & 21.3 \\
1981 & $1,017.8$ & 286.4 & 3.2 & 3.0 & 5.7 & 24.7 & 38.4 \\
1991 & $1,176.1$ & 398.4 & 7.6 & 9.5 & 15.8 & 30.4 & 72.7 \\
2000 & $1,292.4$ & 407.3 & 12.4 & 22.8 & 43.4 & 64.0 & 77.9 \\
\hline
\end{tabular}

Source: FAO (2003)

\subsection{Prospects and Challenges in Future Food Production}

The present gap between supply and demand of food grains is small in overall Asia, and more particularly in South Asian region. However, in the context of growing population, to meet food grain production targets for 2020 and virtually close the gap between supply and demand, production would have to grow at an average annual growth rate of 2.5 to 3 percent (Gunatilleke, 1998).

Any calculation of agricultural capacity done in response to sustained population growth has to be based on an estimate of the resources available. The more accurate the information about the extent and quality of the potential resources, the more reliable the estimate will be. According to Singh (2000), there are three main variables. The first is the total area of land suitable for tilling. Arable farming is the most productive form of land use. The reserves for potential arable land can be calculated by subtracting the total area now being farmed from the total area which could potentially be cultivated. The second is soil fertility, which varies in different climatic zones. However, here too it is necessary to distinguish between current yield and the theoretical maximum yield. The third variable is the level of consumption of or the target standard of nutrition. A global agroclimatic audit is needed to obtain the first two values - the total cultivable land and fertility of soils. The criteria for assessing nutritional standard are based on our knowledge of human nutritional requirements.

The above mentioned calculation is based on detailed model devised by Dutch agronomists at the Wageningen University of Holland. This model is used to compute the capacity of 222 soil regions to produce carbohydrates by photosynthesis as a function of climatic factors, soil quality, and water supply. Calculation from this model shows that, based on the high standard figure for consumption of $1000 \mathrm{~kg}$ per person per year, if the world population stabilizes at the estimated figure of 11.5 thousand million, it will take 23 percent of the absolute maximum food production of the world to feed them (Singh, 2000).

The calculation of the maximum possible food production from all the cultivable land of the earth is a purely theoretical exercise, and is based on the assumption that optimum farming methods are being used everywhere. It takes no account of economic, social, political, and natural constraints. Nor does it take into account the ecological impacts of the progressive replacement of trees and other forms of vegetation by intensively farmed arable land and pasture. It is also important not to undermine the huge input of time, capital, research

G. Singh. "Population and Food Production: Prospects and Challenges for Asia". Agricultural Engineering International: the CIGR Journal of Scientific Research and Development". Vol. V. Invited Overview Paper. Presented at the Forum on Bioproduction in East Asia:

Technology Development \& Opportunities. ASAE Annual meeting, Las Vegas. 27July2003. 
effort, and education needed to bring yields close to the theoretical maximum. From practical consideration, following challenges need to be faced in attaining sufficient food production for growing population in coming decades.

- Weather fluctuation and climatic change: Although the trend of global warming is becoming increasingly clear, its effects on food production are still uncertain. Research suggests that growing conditions will deteriorate in current tropical areas, including Asia. Therefore, policies and technologies should be developed to effectively prevent the negative effects of global warming.

- Growing water scarcity: Unless properly managed, fresh water may well emerge as the key constraint to global food production. While supplies of water are adequate in the aggregate to meet demand for the foreseeable future, water is poorly distributed across countries, within countries, and between seasons. In most of the Asian countries, per capita water availability is steadily declining, as the amount of renewable water resources remains fixed to meet the needs of growing population. Growth in irrigated areas is projected to slow in next decades. In developing countries, total irrigated area was 161 million hectares in 2000 (FAO, 2003), which is projected to reach 227 million hectares in 2020 (Rosegrant et al, 2001). The agriculture sector is by far the largest water user in most of the Asian countries. Appropriate policies and measures will be needed to improve efficiency in water use, and to boost crop production per unit of water.

- Declining soil fertility: Improved soil fertility is a crucial component of lowincome countries' drive to increase sustainable agricultural production. Although some of the soil plant nutrient requirements can be met through the application of organic materials available on the farm, such materials are insufficient to replenish the plant nutrients removed from the soils and thus to further increase crop yields. The total amount of chemical fertilizers used in Asia-Pacific region increased from 51 million tons in 1990 to 70 million tons in 1999 (FAO, 2003). Although reduced use of chemical fertilizers is warranted in some locations because of negative environmental effects, it is critical that fertilizer use be expanded in countries where soil fertility is low and a large share of the population is food insecure. Of particular importance to maintaining and enhancing soil fertility is the adoption of integrated plant nutrient management (IPNM) practices. The goal of IPNM is to integrate the use of natural and manmade sources of plant nutrients to increase the productivity in an efficient and environmentally benign manner without diminishing the productive capacity of soil for present and future generations.

- Declining official development finance: Official development finance has fallen almost 42 percent between 1991 and 2000. Between 1995 and 1996 alone, official development finance declined by almost 25 percent (Rosegrant, et al, 2001). Of course, in real terms the reduction is even sharper. The amount of financial aid from bilateral and multilateral donors to developing countries is expected to decline further in near future due to so-called "structural adjustment policy"

\footnotetext{
G. Singh. "Population and Food Production: Prospects and Challenges for Asia". Agricultural Engineering International: the CIGR Journal of Scientific Research and Development". Vol. V. Invited Overview Paper. Presented at the Forum on Bioproduction in East Asia:

Technology Development \& Opportunities. ASAE Annual meeting, Las Vegas. 27July2003.
} 
adopted by the World Bank and other major donors. Agriculture had been one of the sectors to suffer the most from the decline in international assistance to developing countries.

\section{SUSTAINABLE FOOD SECURITY FOR ASIA}

\subsection{Sustainable Food Security}

The world Food Summit in 1996 defined 'sustainable food security' as a situation in which "all people at all times have physical and economic access to sufficient, safe and nutritious food to meet their dietary needs, and food preferences for an active and healthy life". This seems a helpful definition because it emphasizes the importance of access to food over food production. We must be clear that poverty and food insecurity are closely linked. A review of the "Voices of the Hunger" showed that hunger is central to people's experience of poverty. In many societies poverty is defined in terms of hunger. The World Food Summit secured international commitment to reducing the number of undernourished people by half by the year 2015. FAO estimate suggests that progress to date has been slow. Five years later some 800 million people, mainly women and children, remain food insecure (Short, 2001).

The debate on how to improve food security globally has, until recently, been much too closely associated with food production. Of course we must take into account of our global capacity to feed the population of the world. But old ideas that focus on national selfsufficiency in food rather than national capacity to purchase the food that is needed are outdated. And those who focus their efforts simply on increasing agricultural production must be under no illusions that they will therefore help the poor to obtain food (Eid, 2001).

We need to be clear that most people buy food rather than produce it. Very few people, including small-scale farmers are entirely self-sufficient in food production. Food security and hunger are related to poverty and inability to purchase food. For example, in parts of Northeast India, many poor communities are dependent on rainfed farming for their livelihood. They are rarely self-sufficient in food, and many migrate to the cities when food supplies run out. Department for International Development (DFID) funded programmes increased crop yield of these areas by about 50 percent. But these increases in productivity did not adequately address the problem of seasonal food security for most families. What was needed was diversification of livelihoods beyond agricultural production so that communities had the income to purchase food for the hungry months (Short, 2001).

\subsection{Progress Made to Date}

Even though an unacceptable high number of people live with food insecurity, significant progress has been made, albeit too slowly and unevenly, in improving food security and human well-being in general, over the last three decades. In spite of rapid population growth the number of food-insecure people in developing countries declined from 994 million in 1970 to 800 million in 2000 (IFPRI, 2001). But progress has been uneven, with major improvements occurring in East and South-East Asia. While the number of foodinsecure people increased in South Asia, it more than doubled in Sub-Saharan Africa.

G. Singh. "Population and Food Production: Prospects and Challenges for Asia". Agricultural Engineering International: the CIGR Journal of Scientific Research and Development". Vol. V. Invited Overview Paper. Presented at the Forum on Bioproduction in East Asia:

Technology Development \& Opportunities. ASAE Annual meeting, Las Vegas. 27July2003. 


\subsection{Driving Forces for Sustainable Food Security}

There are many factors that will influence the prospects for sustainable food security in coming decades. Nine sets of driving forces are believed to be of global importance, and more particularly relevant to Asia's context, which are as follows (Rosegrant et al, 2001):

$>$ Accelerating globalization: Globalization offers developing countries new opportunities for broad-based economic growth and poverty reduction. However, it carries significant risks. Continued protection of domestic agriculture and increasing safety concerns in industrialized countries may limit access to their markets by developing countries. The most critical issue is how globalization can be guided to benefit low-income people, particularly their food and nutrition situation, as well as the impact on natural resources. Without appropriate policies and institutions at both the national and international levels, globalization may either bypass or harm many poor people in developing countries.

$>$ Sweeping technological changes: New technological advances in molecular biology and information and communications offer potential benefits for poor people that may advance food security and improve the sustainability of natural resource management. However, there are serious concerns over whether poor and food-insecure people will have access to these technologies.

$>$ Degradation of natural resources and increasing water scarcity: Degradation of natural resources is rampant in many resource-poor areas of developing countries, particularly those areas with fragile soils, irregular rainfall, relatively high population density, and stagnant productivity in agriculture. While natural resource degradation often is a consequence of poverty, it also contributes to poverty. Water scarcity is emerging as a most limiting factor for food security in many regions.

$>$ Emerging health and nutrition crises: The tragic pandemic of AIDS, the persisting threats from malaria, the re-emergence of tuberculosis, the widespread prevalence of micronutrient deficiencies, and a variety of chronic diseases compromise food security in many developing countries. Achieving food-secure world for all calls for a healthy population.

$>$ Rapid urbanization: Most of the population increases in coming years will occur in cities and towns of developing countries. By the year 2020, a majority of the developing world's population will live in urban areas. This will present new challenges to provide employment, education, health care, and food. While current actions must continue to focus on the rural areas where the majority of the poor and food insecure people reside, future policy actions must pay increasing attention to the growing poverty and food insecurity in urban areas.

$>$ Rapid changing structure of farming: A number of factors such as the aging of the farm population, the feminization of agriculture, the labour shortages and depleting asset bases, and the decreasing cost of capital relative to labour are conspiring to result

G. Singh. "Population and Food Production: Prospects and Challenges for Asia". Agricultural Engineering International: the CIGR Journal of Scientific Research and Development". Vol. V. Invited Overview Paper. Presented at the Forum on Bioproduction in East Asia:

Technology Development \& Opportunities. ASAE Annual meeting, Las Vegas. 27July2003. 
in rapid changes in the structure of farming in many developing countries. These rapidly emerging factors call for new and innovative approaches to agricultural policy and rural institutions. Small-scale farms, which traditionally have been considered the backbone on much of developing-country agriculture, are under threat as labour scarcity caused by out-migration.

$>$ Continued conflict: Violent conflicts continue to cause severe human misery in a large number of developing countries. The impact of these conflicts on food security, nutrition, and natural resource management are severe. While humanitarian assistance may be effective in providing food and shelter for millions of refugees, policy action is needed to deal with the underlying causes and the resulting impact on the people in war-torn and neighbouring areas. Achieving sustainable food security for all is unlikely to be possible in the midst of conflict.

> Climate change: Future policy action to achieve sustainable food security must incorporate the likely consequences of the ongoing climate change and associated fluctuations in weather patterns. Policies and institutions will be needed to counter or compensate for negative effects. While agriculture may contribute to or reduce the increasing concentration of carbon dioxide $\left(\mathrm{CO}_{2}\right)$ in the air, the primary responsibility of future policies will be to find ways to accommodate agriculture, and natural resources as the climate change continues.

> Changing roles and responsibilities of key institutions: The diminished and changing role of national governments in many developing countries, which has been under way over the last couple of decades, is likely to continue in future. Local governments along with the private sector and civil society are taking on an increasing responsibility for activities previously undertaken by national governments. Local communities, frequently with the help of community-based non-governmental organizations, are demanding an increasing say in policies and programmes that impinge on them. At the global level, transnational corporations and broad coalitions of civil society organizations are taking on increasingly prominent roles in policy debate and in national and international policy formulation. New emphasis on exposing corruption where it occurs is likely to contribute to the ongoing changes in the roles and responsibilities of various actors.

\subsection{Priority Areas of Action}

Achieving sustainable food security for Asia will depend on appropriate policy action and institutions that address the causes of food insecurity, malnutrition, and faulty management of natural resources, within the context of above mentioned driving forces. The specific policies that will be most appropriate will vary according to regional, national, and local circumstances. According to IFPRI (2001), priority policy action should include the following major areas:

- Investing in human resources: Investing in human resources is essential to reduce human misery. Healthy, well-nourished, literate citizens are an important precondition for successful pro-poor economic growth. Governments and international

G. Singh. "Population and Food Production: Prospects and Challenges for Asia". Agricultural Engineering International: the CIGR Journal of Scientific Research and Development". Vol. V. Invited Overview Paper. Presented at the Forum on Bioproduction in East Asia:

Technology Development \& Opportunities. ASAE Annual meeting, Las Vegas. 27July2003. 
agencies should address health risks that compromise food security as a key part of any comprehensive effort to achieve food security and poverty reduction. As agricultural labour become depleted, new production technologies and varieties need to be developed that do not rely so much on labour. Food-for-education programmes can be effective in achieving the dual goal of better education and improved food security for poor people in the developing countries.

- Improving access to productive resources and employment: Sustainable food security requires that poor people have access to productive resources and employment. Efforts to generate pro-people economic growth will succeed if such access exists. As most of poor people in developing countries live in rural areas, productivity gains in agriculture, which will boost rural incomes on and off the farm, are crucial. There is considerable evidence that increases in farm income in developing countries promote strong income increases in the rest of the economy. Poor farmers need access to yield-increasing crop varieties and production technologies. Making institutions, including agricultural research centers, more client focused can help natural resource management.

- Improving markets, infrastructure and institutions: Without access to wellfunctioning markets for farm inputs and outputs, the benefits from improved human resources and access to productive resources will not be fully captured by foodinsecure people. The development of private competitive markets along with the supporting institutions and infrastructure is likely to contribute enormously to poverty reduction, food security, and the overall quality of life in developing countries. Yet even as the government reduces its role, competent public administration will remain essential to ensure that contracts are enforced; grading and quality control standards are enacted; investments are properly regulated; and competitive markets are facilitated to reach poor people.

- Expanding appropriate research, knowledge and technology: Technological developments in the biological sciences, energy, and information and communications offer new opportunities that could benefit poor people. These benefits will be materialized if policies are in place to guide technology development towards solving poor's problems. The primary role of government should be to make available to small farmers a list of technology options from which they can choose an option for them. Because of past negligence of less-favoured areas, such a list of technology options is particularly crucial for these areas. Participatory research will be needed, so that the options are relevant and appropriate to the intended beneficiaries and they are in a position to make choices.

- Improving natural resource management: While intensification of agricultural production has led to environmental degradation in many industrialized countries and few regions of developing countries, the most critical natural resource management problem in developing countries is poverty and low agricultural productivity leading to exploitation of natural resources. Policies and institutions should be put in place to break the vicious downward spiral of poverty, low agricultural productivity, and environmental degradation.

G. Singh. "Population and Food Production: Prospects and Challenges for Asia". Agricultural Engineering International: the CIGR Journal of Scientific Research and Development". Vol. V. Invited Overview Paper. Presented at the Forum on Bioproduction in East Asia:

Technology Development \& Opportunities. ASAE Annual meeting, Las Vegas. 27July2003. 
- Good governance: Good governance, including the rule of law, transparency, lack of corruption, conflict resolution, is of critical importance to assure sustainable food security. While the role of the state has changed markedly in many developing countries in recent years, national governments are still the most appropriate and major suppliers of essential public goods. Where national governments fail to take appropriate action, food security fails. Hunger persists largely because of governance and policy failure at the national level.

- Sound national and international trade and macro-economic policies: National and international policies and institutions are needed to guide globalization for the benefit of the poor. Stable and predictable macro-economic policies along with sectoral policies and investments in infrastructure should be pursued within a sound governance framework. As globalization proceeds, new international institutions may be needed to assure that low-income people and low-income countries benefit. Industrialized countries should accelerate access by developing countries in their markets, and the WTO should work closely with civil societies and national governments to identify and remove factors that are adverse to poor people. From the side of the developed countries and international organizations, ongoing negotiations for debt relief for low-income countries should be accelerated.

\section{CONCLUSION}

It has become widely accepted that "political will" is the key ingredient in any recipe for sustainable food security. Political will neither come from heaven - nor from summits or conferences. It is driven by pressure from below and must come from those who are hungry and poor. Political will means more than assenting to declarations filled with ringing rhetoric. It means a high place for food security on the policy agenda, new programmes and institutions, new partnerships, and new ways of thinking, and most of all, economic and political empowerment of poor people. Collective empowerment of the poor requires new political initiatives and new partnerships between national and international stakeholders.

Finally, as stated by Singh (2000), sustainable food security in the Asian (developing) countries can be achieved if there is strong political will to provide following five "Is" for agricultural growth and improved livelihood in rural areas:

- Incentives: Remunerative prices for agricultural produce and products.

- Innovation: Strong national agricultural education, research and extension systems (both public and private) to generate and disseminate productivity-enhancing technologies.

- Infrastructure: Good roads and transport systems, power supply and irrigation systems.

G. Singh. "Population and Food Production: Prospects and Challenges for Asia". Agricultural Engineering International: the CIGR Journal of Scientific Research and Development". Vol. V. Invited Overview Paper. Presented at the Forum on Bioproduction in East Asia:

Technology Development \& Opportunities. ASAE Annual meeting, Las Vegas. 27July2003. 
- Inputs: Efficient delivery systems for agricultural services, especially for modern farm inputs, agro-processing and credit.

- Institutions: Efficient, liberalized markets that provide farmers with ready access to domestic and international markets and effective public institutions to provide key services where these cannot be devolved by the private sector.

\section{REFERENCES}

Aziz, S. 2001. Eight hundred million still hungry: Why have we made so little progress? IFPRI, Washington D.C.

BBS. 2001. Statistical yearbook of Bangladesh. Bangladesh Bureau of Statistics, Ministry of Planning, Dhaka.

Bongaarts, J. 2001. Future population trends. IFPRI, Washington D.C.

CBSL. 2000. Annual report. Central Bank of Sri Lanka, Colombo.

Dyson, T. 1996. Population and food: Global trends and future prospects. Routledge, London and New York.

Eid, U. 2001. The roles and responsibilities of industrialized countries in assuring sustainable food security: Setting priorities for action. IFPRI, Washington D.C.

FAO. 2003. FAOSTAT database, <http://www.fao.org >.

Gunatilleke, G. 1998. The 2020 vision for food, agriculture, and the environment: Continuing dialogue. IFPRI, Washington D.C.

Hai, N.V. 1998. Agricultural planning in Vietnam. Proceedings of a workshop held in Bogor, Indonesia during 13-24 April, 1998. The CGPRT Centre, Bogor, Indonesia. pp. 215-221.

ICAR. 2002. Agricultural research data book, 2002. Indian Council of Agricultural Research and Indian Agricultural Statistics Research Institute, New Delhi.

IFPRI. 2001. Sustainable food security for all by 2020. IFPRI, Washington D.C.

Joshi, S.K. and Poundyal. 1998. NARC's project budget: An analytical review. Nepal Agricultural Research Council, Katmandu.

Kerr, J. 2000. Development strategies for semiarid South Asia. Brief \# 6, Promoting sustainable development in less-favoured areas. IFPRI, Washington D.C.

Meyers, H.W. 2001. Success and failures in achieving the goals of the world food summit. IFPRI, Washington D.C.

G. Singh. "Population and Food Production: Prospects and Challenges for Asia". Agricultural Engineering International: the CIGR Journal of Scientific Research and Development". Vol. V. Invited Overview Paper. Presented at the Forum on Bioproduction in East Asia:

Technology Development \& Opportunities. ASAE Annual meeting, Las Vegas. 27July2003. 
NEDA. 2001. Full year economic review: 2002 growth projections. National Economic Development Authority, Republic of Philippines, Manila.

Oerke, E.C., Denhe, H.W., Schonbeck, F. and Weber, A. 1994. Crop production and Crop protection. Elsevier Science B.V., Amsterdam.

Pandey, S. 2000. Technologies for the South-East Asian uplands. Brief \# 4, Promoting sustainable development in less-favoured areas. IFPRI, Washington D.C.

Roonnaphai, N. 1998. Agricultural planning in Thailand. Proceedings of a workshop held in Bogor, Indonesia during 13-24 April, 1998. The CGPRT Centre, Bogor, Indonesia. pp. 297-213.

Rosegrant, M.W., Paisner, M.S., Meijer, S. and Witcover, J. 2001. Global food projections to 2020: Emerging trends and alternative futures. IFPRI, Washington D.C.

Short, C. 2001. Food insecurity: A symptom of poverty. IFPRI, Washington D.C.

Singh, G. 2000. Population and food: Why India is prospering instead of starving? In Growth Unlimited, Proceedings of $6^{\text {th }}$ SERD Seminar. School of Environment, Resources and Development, Asian Institute of Technology, Bangkok, Thailand. pp.17-30.

Suhaeti, R.N. 1998. Agricultural research management in Indonesia. Proceedings of a workshop held in Bogor, Indonesia during 13-24 April, 1998. The CGPRT Centre, Bogor, Indonesia. pp. 151-161.

UNDP. 2003. Human development reports. $<$ http://hdr.undp.org $>$

UNFPA. 2003. Demographic trends by region. $<$ http://unfpa.org $>$

G. Singh. "Population and Food Production: Prospects and Challenges for Asia". Agricultural Engineering International: the CIGR Journal of Scientific Research and Development". Vol. V. Invited Overview Paper. Presented at the Forum on Bioproduction in East Asia:

Technology Development \& Opportunities. ASAE Annual meeting, Las Vegas. 27July2003. 